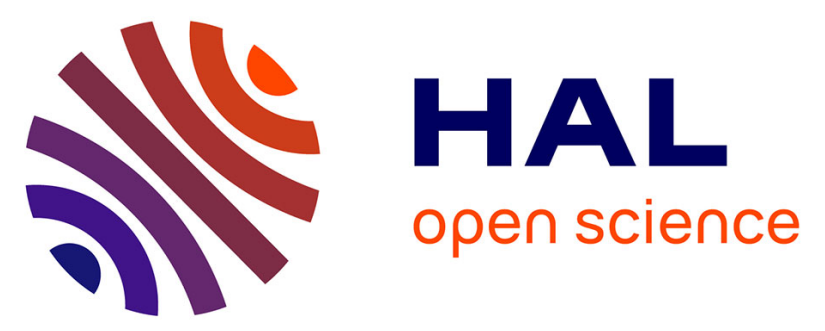

\title{
Magnetic susceptibility as a proxy for investigating microbially mediated iron reduction
}

Farag M. Mewafy, Estella A. Atekwana, D. Dale Werkema Jr., Lee D. Slater, Dimitrios Ntarlagiannis, André Revil, Magnus Skold, Geoffrey N. Delin

\section{- To cite this version:}

Farag M. Mewafy, Estella A. Atekwana, D. Dale Werkema Jr., Lee D. Slater, Dimitrios Ntarlagiannis, et al.. Magnetic susceptibility as a proxy for investigating microbially mediated iron reduction. Geophysical Research Letters, 2011, 38, pp.L21402. 10.1029/2011GL049271 . insu-00681303

\section{HAL Id: insu-00681303 https://hal-insu.archives-ouvertes.fr/insu-00681303}

Submitted on 11 Mar 2021

HAL is a multi-disciplinary open access archive for the deposit and dissemination of scientific research documents, whether they are published or not. The documents may come from teaching and research institutions in France or abroad, or from public or private research centers.
L'archive ouverte pluridisciplinaire HAL, est destinée au dépôt et à la diffusion de documents scientifiques de niveau recherche, publiés ou non, émanant des établissements d'enseignement et de recherche français ou étrangers, des laboratoires publics ou privés. 


\title{
Magnetic susceptibility as a proxy for investigating microbially mediated iron reduction
}

\author{
Farag M. Mewafy, ${ }^{1}$ Estella A. Atekwana, ${ }^{1}$ D. Dale Werkema Jr., ${ }^{2}$ Lee D. Slater, ${ }^{3}$ \\ Dimitrios Ntarlagiannis, ${ }^{3}$ André Revil, ${ }^{4}$ Magnus Skold, ${ }^{4}$ and Geoffrey N. Delin ${ }^{5}$ \\ Received 11 August 2011; revised 7 October 2011; accepted 11 October 2011; published 9 November 2011.
}

[1] We investigated magnetic susceptibility (MS) variations in hydrocarbon contaminated sediments. Our objective was to determine if MS can be used as an intrinsic bioremediation indicator due to the activity of ironreducing bacteria. A contaminated and an uncontaminated core were retrieved from a site contaminated with crude oil near Bemidji, Minnesota and subsampled for MS measurements. The contaminated core revealed enriched MS zones within the hydrocarbon smear zone, which is related to iron-reduction coupled to oxidation of hydrocarbon compounds and the vadose zone, which is coincident with a zone of methane depletion suggesting aerobic or anaerobic oxidation of methane is coupled to iron-reduction. The latter has significant implications for methane cycling. We conclude that MS can serve as a proxy for intrinsic bioremediation due to the activity of iron-reducing bacteria iron-reducing bacteria and for the application of geophysics to iron cycling studies. Citation: Mewafy, F. M., E. A. Atekwana, D. D. Werkema Jr., L. D. Slater, D. Ntarlagiannis, A. Revil, M. Skold, and G. N. Delin (2011), Magnetic susceptibility as a proxy for investigating microbially mediated iron reduction, Geophys. Res. Lett., 38, L21402, doi:10.1029/2011GL049271.

\section{Introduction}

[2] The Deepwater Horizon spill in the Gulf of Mexico is a reminder of the environmental threat of hydrocarbon contamination and the need for technological advancements for detecting, monitoring, and remediating hydrocarbon contamination. Due to the relationship between magnetic minerals and redox reactions associated with hydrocarbon seeps, magnetic susceptibility (MS) has been used as a possible tool for oil exploration [e.g., Saunders et al., 1999]. In surficial sediments, MS traditionally is used for climate studies [e.g., Kukla et al., 1988], mapping heavy metal soil contamination [e.g., Hanesch and Scholger, 2002], and identifying sediment sources and transport trends [Ellwood et al., 2006]. MS has recently emerged as a tool for investigating iron cycling mediated by microbial activity [e.g., Porsch et al., 2010; Rijal et al., 2010].

\footnotetext{
${ }^{1}$ Boone Pickens School of Geology, Oklahoma State University, Stillwater, Oklahoma, USA.

${ }^{2}$ U.S. Environmental Protection Agency, Las Vegas, Nevada, USA.

${ }^{3}$ Department of Earth and Environmental Sciences, Rutgers University, Newark, New Jersey, USA.

${ }^{4}$ Department of Geophysics, Colorado School of Mines, Golden, Colorado, USA.

${ }^{5}$ U.S. Geological Survey, Denver, Colorado, USA.

Copyright 2011 by the American Geophysical Union. 0094-8276/11/2011GL049271
}

[3] This work investigates MS variations in a hydrocarbon contaminated aquifer where methanogenesis and ironreduction are the main terminal electron acceptor processes [Baedecker et al., 1993]. Our objective was to determine if MS could be an indicator of the presence of intrinsic hydrocarbon bioremediation by iron-reducing bacteria. Our results suggest enhancements in MS are due to the precipitation of magnetite coupled to iron-reduction as related to; (1) anaerobic oxidation of hydrocarbon compounds within the smear zone and (2) aerobic or anaerobic oxidation of methane within the vadose zone, which provides additional field evidence linking anaerobic oxidation of methane to iron-reduction and suggests significant implications for methane cycling in terrestrial environments.

\section{Site History}

[4] The crude oil spill near Bemidji, Minnesota (Figure 1), is a field laboratory for investigating biogeophysical signatures associated with intrinsic bioremediation. In August 1979, a high pressure crude oil pipeline ruptured, releasing $1,700,000 \mathrm{~L}$ of crude oil. The study site consists of $\sim 20 \mathrm{~m}$ thick moderately calcareous sand and outwash glacial deposits overlying clayey till of unknown thickness [Bennett et al., 1993]. Iron minerals in sediments include goethite, hematite, magnetite, ferrihydrite, and maghemite [Bekins et al., 2001].

[5] The uncontaminated groundwater is aerobic with dissolved oxygen concentrations between 8 and $9 \mathrm{mg} / \mathrm{L}$, dissolved organic carbon of $2.8 \mathrm{mg} / \mathrm{L}$ as $\mathrm{C}$, and low levels of nitrate at generally $<0.2 \mathrm{mg} / \mathrm{L}$ and sulfate at $2.9 \mathrm{mg} / \mathrm{L}$ [Bennett et al., 1993]. The aquifer is divided in the vicinity of the oil body into anoxic, transition, and background zones. In the anoxic portion, hydrocarbons are oxidized predominantly by iron reduction [Lovley et al., 1989] and methanogenesis [e.g., Baedecker et al., 1993]. Bekins et al. [2001] show two zones of methanogenic activity with $\mathrm{CH}_{4}$ concentrations greater than $15 \mathrm{mg} / \mathrm{L}$. The vadose zone vapor plume near the oil body has low $\mathrm{O}_{2}(<2 \%)$ and high $\mathrm{CO}_{2}$ $(>10 \%)$ and $\mathrm{CH}_{4}(>15 \%)$ levels.

\section{Materials and Methods}

\subsection{Retrieval of Cores}

[6] Two $\sim 5-\mathrm{cm}$ diameter cores were retrieved from contaminated (C1010) and uncontaminated (C1006) locations (Figure 1). Whereas the contaminated core was continuously collected, two segments of core were collected from the uncontaminated location. The cores were collected by advancing a core barrel with a polycarbonate liner ahead of a hollow-stem auger. The cores within the smear zone or 


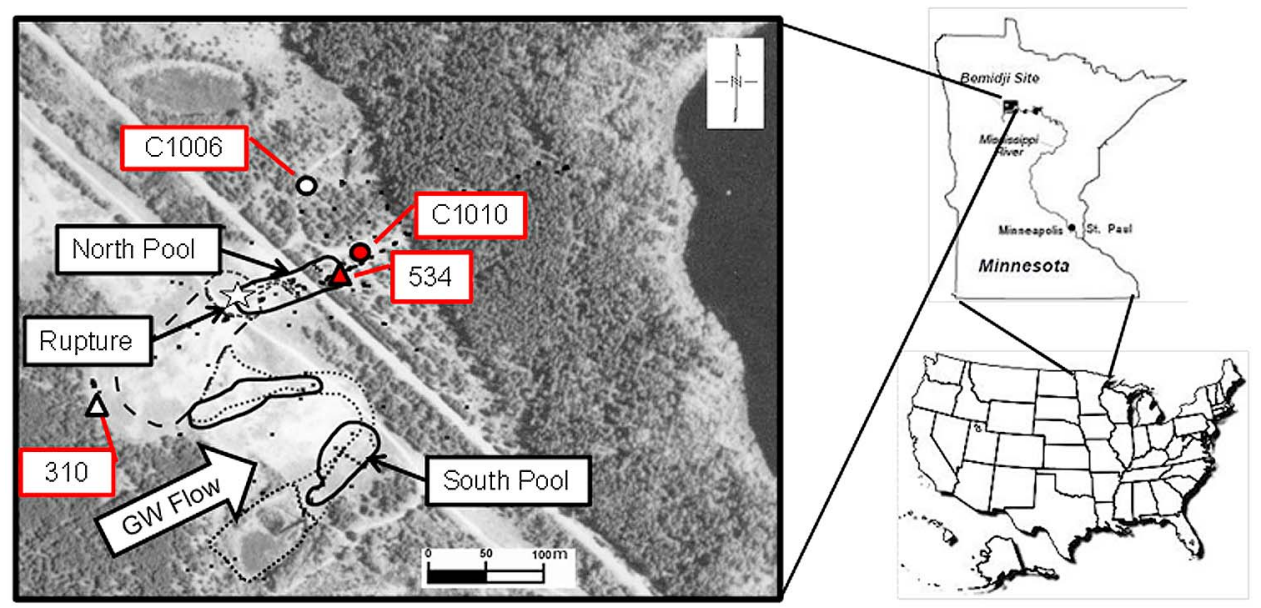

Figure 1. Study area showing the location of core samples (circles) and gas data (triangles) at contaminated (closed symbols) and uncontaminated (opened symbols) boreholes. 310 and 534 are vadose zone gas sampling boreholes.

below the water table were collected with a freezing drive shoe [Murphy and Herkelrath, 1996], preserved in coolers unexposed to the atmosphere, and shipped to the laboratory at Oklahoma State University.

\subsection{MS Measurements and Iron Analysis}

[7] Sub-samples of $\sim 10$ grams were taken at 5 to $15 \mathrm{~cm}$ intervals along the cores. Sub-samples were oven dried at $50^{\circ} \mathrm{C}$ for 24 hours then analyzed for MS using a Bartington MS2 magnetic susceptibility meter $\left(1.2566 \times 10^{-11} \mathrm{~m}^{3} / \mathrm{kg}\right.$ sensitivity). Then the same samples were used to quantify iron content. The mass of magnetic particles retained by a bar magnet was measured and the percentage of the ironrich material per sample was determined.

\subsection{Gas Data}

[8] Vapor wells 534 (contaminated) and 310 (uncontaminated) (Figure 1) consisted of permanently installed vapor probes generally spaced at $50-$ to $100-\mathrm{cm}$ depth intervals in the unsaturated zone, from $1 \mathrm{~m}$ below land surface to $1 \mathrm{~m}$ above the water table [Chaplin et al., 2002]. Each probe was constructed of $0.16-$ to $0.64-\mathrm{cm}$ outside diameter stainless steel tubing with 5 to $10-\mathrm{cm}$ long screens at the bottom. The probes were installed in 10-cm-diameter augered holes, which were backfilled with native sand, and included a bentonite seal between each screened interval. The gas samples were obtained in gas-tight glass syringes using a peristaltic pump and analyzed on-site using a SRI® $8610 \mathrm{C}$

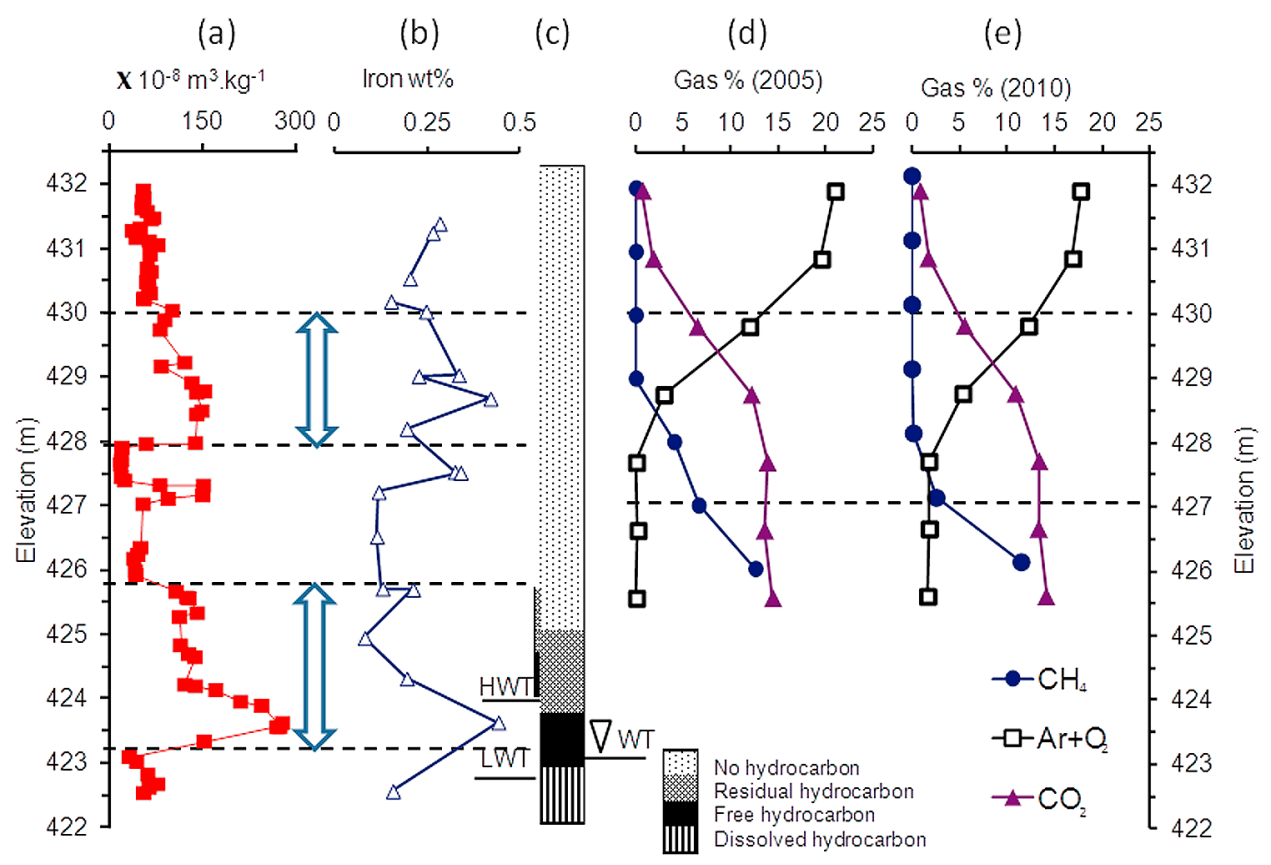

Figure 2. (a) Magnetic susceptibility, (b) iron wt \%, (c) hydrocarbon distribution within core, gas concentrations in (d) 2005, and (e) 2010 along the contaminated core (C 1010). HWT: Highest water level, LWT: Lowest water level and WT: Water Table during the time of measurements. Elevation above mean sea level (amsl). The gas data are from location 534 located $10 \mathrm{~m}$ from $\mathrm{C} 1010$. 


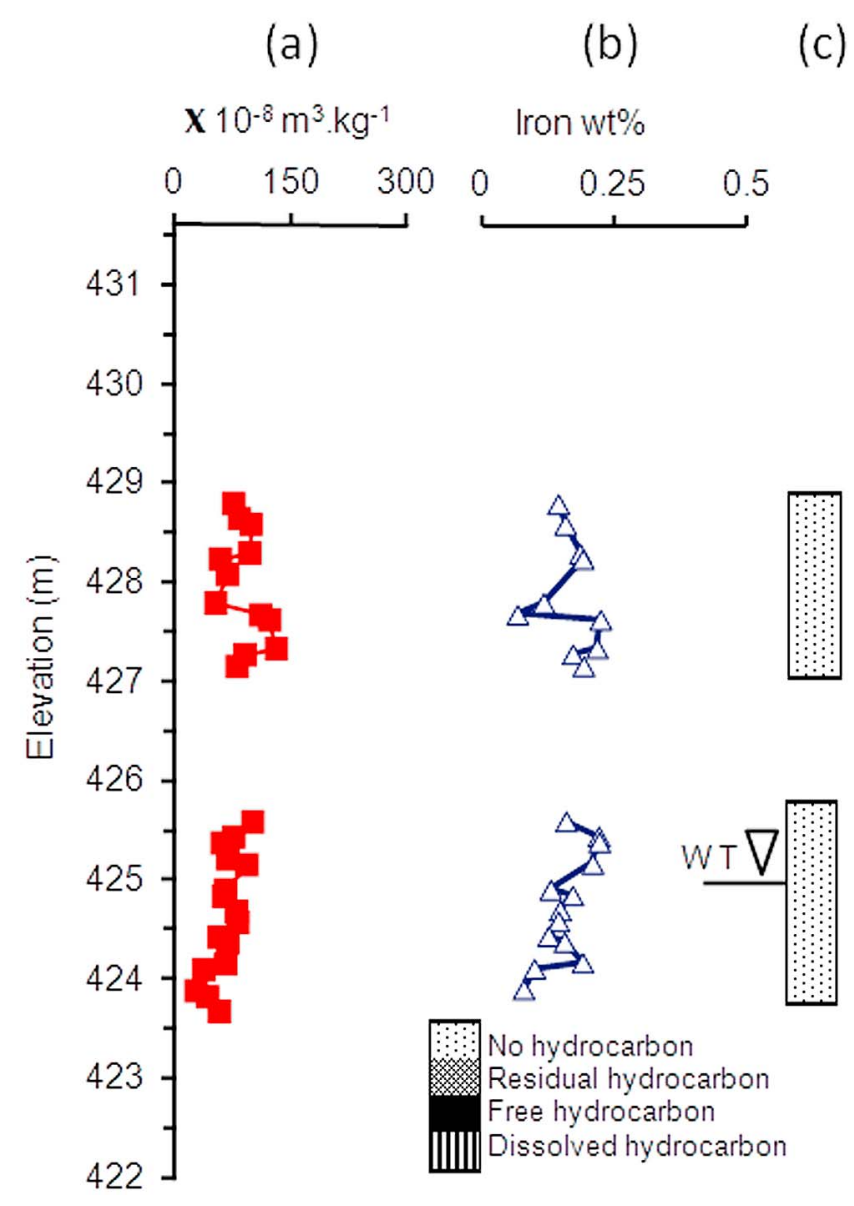

Figure 3. (a) Magnetic susceptibility, (b) iron wt \%, and (c) hydrocarbon distribution in two 2-m zones along the uncontaminated borehole (C 1006). WT: Water Table during the time of measurements. Elevation above mean sea level (amsl).

Gas Chromatograph (GC). The GC was configured using a 1.0-mL fixed-loop injection and an internal air compressor. Fixed gas $\left(\mathrm{Ar}, \mathrm{O}_{2}, \mathrm{CO}_{2}\right.$, and $\left.\mathrm{CH}_{4}\right)$ analyses were determined with a thermal conductivity detector (TCD) and a SRI ${ }^{\circledR}$ CTR-1 double-packed column. Concentrations of gases were quantified in weight percent using gas standards containing mixtures of $\mathrm{Ar}, \mathrm{O}_{2}, \mathrm{CO}_{2}$, and $\mathrm{CH}_{4}$.

\section{Results}

\subsection{Magnetic Susceptibility}

[9] The contaminated core showed two zones of high MS (Figure 2a) versus the uncontaminated core (Figure 3a). The first zone was located from $\sim 423 \mathrm{~m}$ at the base of the free hydrocarbon to $\sim 426 \mathrm{~m}$ at the top of the groundwater table (GWT) where the MS values ranged from 75 to $299 \times$ $10^{-8} \mathrm{~m}^{3} \mathrm{~kg}^{-1}$ reaching a maximum at $423.5 \mathrm{~m}$ (Figure $2 \mathrm{a}$ ). The second zone was between 428-429 $\mathrm{m}$ where the MS values ranged between 88 to $218 \times 10^{-8} \mathrm{~m}^{3} \mathrm{~kg}^{-1}$ to a maximum at $\sim 428.5 \mathrm{~m}$ (Figure $2 \mathrm{a}$ ). Another zone of high MS was observed at $427.2 \mathrm{~m}$. This high MS zone occurs within the vadose zone with no corresponding free or residual hydrocarbon contamination (Figure 2c). The MS of the uncontaminated core showed relatively small var- iations with no anomalous zones and values ranging from 40 to $145 \times 10^{-8} \mathrm{~m}^{3} / \mathrm{kg}$ (Figure $3 \mathrm{a}$ ).

\subsection{Magnetic Minerals Analysis}

[10] The measurements of the iron wt \% in the uncontaminated core showed no anomalous concentrations with values ranging from 0.07 to 0.22 and an average value of $0.14 \mathrm{wt} \%$. In contrast, the contaminated core showed elevated values between 0.19 to $0.44 \mathrm{wt} \%$, reaching a maximum at $423.5 \mathrm{~m}$ at depths coincident with higher MS (Figure 2b). In the 428-430 $\mathrm{m}$ elevation interval, the iron wt $\%$ ranged between 0.19 to 0.42 wt \% with a maximum at $429 \mathrm{~m}$. The correlation between MS and magnetite, obtained by plotting MS versus magnetite suggests that magnetite is responsible for the MS variations with an $\mathrm{R}^{2}$ of 0.817 and 0.967 for the contaminated and uncontaminated cores, respectively. XRD analyses (Figure S1 in the auxiliary material) suggested that magnetite was the dominant phase. $^{1}$

\subsection{Distribution of $\mathrm{Ar}+\mathrm{O}_{2}, \mathrm{CH}_{4}$ and $\mathrm{CO}_{2}$}

[11] In 2005, the $\mathrm{CO}_{2}$ concentrations increased from nearly $0.7 \%$ at ground surface to $6.5 \%$ at $430 \mathrm{~m}$ and $12.2 \%$ at $429 \mathrm{~m}$. Ar and $\mathrm{O}_{2}$ concentrations decreased downward to less than $11.9 \%$ at $430 \mathrm{~m}$ to $2.9 \%$ at $429 \mathrm{~m}$ and are depleted at $428 \mathrm{~m} . \mathrm{CH}_{4}$ showed depletion upwards from about $4 \%$ at $427 \mathrm{~m}$ to $0 \%$ at $429 \mathrm{~m}$ (Figure $2 \mathrm{~d}$ ). These data define a transition zone from $\sim 427 \mathrm{~m}$ to $430 \mathrm{~m}$ where $\mathrm{O}_{2}$ and $\mathrm{CH}_{4}$ are depleted and $\mathrm{CO}_{2}$ is enriched. The same trends occur in the 2010 data; however, the transition zone has shifted to a lower elevation (Figure 2e). The uncontaminated gas concentration profile showed no variability as compared to atmospheric values.

\section{Discussion and Conclusions}

[12] Geochemical and microbial studies suggest iron reduction is an important terminal electron acceptor process occurring within the anaerobic plume [e.g., Baedecker et al., 1993]. In addition, iron-reducing bacteria such as Geobacter bemidjiensis sp. and Geobacter psychrophilus sp occur in the contaminated aquifer [Nevin et al., 2005]. During iron reduction, $\mathrm{Fe}^{3+}$ is converted to $\mathrm{Fe}^{2+}$ : which can be oxidized by the protons of water to form magnetite:

$$
3 \mathrm{Fe}(\mathrm{OH})_{2} \rightarrow \mathrm{Fe}_{3} \mathrm{O}_{4 \mathrm{~s}}+\mathrm{H}_{2}+2 \mathrm{H}_{2} \mathrm{O}
$$

\subsection{Smear Zone}

[13] The smear zone above the GWT (423.5-425 m) shows the highest MS values and iron wt \% (Figures 2a-2c). Biogeophysical investigations at other hydrocarbon contaminated sites have documented the highest value of bulk electrical conductivity within this smear zone and suggested it to be most biologically active [Werkema et al., 2003]. Additionally, MS studies by Rijal et al. [2010] show concentrations of magnetic parameters increasing towards the top of the GWT. Thus, we infer this enriched zone of magnetite is due to the anaerobic oxidation of hydrocarbons by iron-reducing bacteria [Lovley et al., 1989]. Microbial

${ }^{1}$ Auxiliary materials are available in the HTML. doi:10.1029/ 2011 GL049271. 
data showed culturable iron reducers were present in the oil layer in 1997 [Bekins et al., 1999].

\subsection{Unsaturated Zone}

[14] The zone of enriched magnetite occurring in the vadose zone (427-430 m) (Figures $2 \mathrm{a}$ and $2 \mathrm{~b}$ ) can be explained by: (1) naturally occurring higher concentration of magnetite within the sediments in this zone, (2) precipitation of magnetite (equations (1) and (2)) related to past hydrocarbon vapors in the vadose zone, (3) precipitation of magnetite (equation (1)), related to aerobic oxidation of methane (equation (2)) which releases water protons that can oxidize $\mathrm{Fe}(\mathrm{OH})_{2}$ to magnetite,

$$
\mathrm{CH}_{4}+2 \mathrm{O}_{2} \rightarrow \mathrm{CO}_{2}+2 \mathrm{H}_{2} \mathrm{O} .
$$

or (4) the precipitation of magnetite resulting from anaerobic oxidation of methane (AOM) coupled to iron reduction.

[15] Although there are presently no hydrocarbon vapors present in the vadose zone, vapors were present in the past [Chaplin et al., 2002]. Hence, the zone of enriched magnetite occurring in the vadose zone at the $427-430 \mathrm{~m}$ elevation (Figure 2a) could represent a relict process of bacterial oxidation of the hydrocarbon vapors coupled to iron reduction. Nevertheless, we favor hypotheses 3 and 4 for the following reason. The gas data (Figures $2 \mathrm{~d}$ and $2 \mathrm{e}$ ) suggest a transition in the methane and oxygen plots crossing at $428.3 \mathrm{~m}$ (2005) and $427.2 \mathrm{~m} \mathrm{(2010),} \mathrm{where} \mathrm{the} \mathrm{total} \mathrm{depletion} \mathrm{of}$ methane occurs. Also, culturable methanotroph microbial population numbers peak within this zone [Molins et al., 2010] (data not shown). This has led some to suggest the aerobic oxidation of methane within this zone [Amos et al., 2005]. It is possible that the precipitation of magnetite in this zone could be linked to the aerobic oxidation of methane (equations (1) and (2)).

[16] The precipitation of magnetite resulting from the anaerobic oxidation of methane (AOM) coupled to iron reduction is also possible. Whereas AOM coupled to sulfate reduction is documented in marine environments [e.g., Hoehler et al., 1994], AOM coupled to metal reduction is not common and has yet to be definitively demonstrated. There are also no known microorganisms capable of this process [Beal et al., 2009]. Nonetheless, recent studies postulate that AOM coupled to metal reduction is likely to occur [e.g., Beal et al., 2009; Crowe et al., 2011]. Beal et al. [2009] show AOM in the absence of sulfate if birnessite or ferrihydrite is present. Crowe et al. [2011] document that, despite high abundances of Fe (hydr)oxides in lake sediments, more than $50 \%$ of authigenic organic matter was degraded through methanogenesis, suggesting methane oxidation and Fe(III) reduction coupling. This mechanism is as follows: (1) AOM coupled with ferrihydrite (simplified as $\left.\mathrm{Fe}(\mathrm{OH})_{3}\right)$ reduction [Beal et al., 2009].

$$
\mathrm{CH}_{4}+8 \mathrm{Fe}(\mathrm{OH})_{3}+15 \mathrm{H}^{+} \rightarrow \mathrm{HCO}_{3}^{-}+8 \mathrm{Fe}^{2+}+21 \mathrm{H}_{2} \mathrm{O} .
$$

Part of the $\mathrm{Fe}^{2+}$ reacts with the small amounts of $\mathrm{O}_{2}$ present, thereby precipitating magnetite:

$$
\begin{gathered}
3 \mathrm{Fe}(\mathrm{OH})_{2}+{ }^{1} / 2 \mathrm{O}_{2} \rightarrow \mathrm{Fe}(\mathrm{OH})_{2} \cdot 2 \mathrm{FeOOH}+\mathrm{H}_{2} \mathrm{O} . \\
\mathrm{Fe}(\mathrm{OH})_{2} \cdot 2 \mathrm{FeOOH} \rightarrow \mathrm{Fe}_{3} \mathrm{O}_{4 \mathrm{~s}}+2 \mathrm{H}_{2} \mathrm{O} .
\end{gathered}
$$

The remaining $\mathrm{Fe}(\mathrm{OH})_{2}$ can be oxidized by water protons to form magnetite (equation (1)).

[17] Geochemical studies at this site show low levels of nitrate $\left(44.8 \mu \mathrm{g} / \mathrm{L}\right.$ as $\left.\mathrm{N}_{2}\right)$ and sulfate $(2.9 \mathrm{mg} / \mathrm{L})$ [Bennett et al., 1993], which, in addition to elevated precipitation of magnetite, supports our argument that this is a zone of methane oxidation coupled with iron reduction. Our study suggests that MS measurements may aid in field investigations of this process. AOM coupled to iron reduction has significant implications for methane cycling in terrestrial environments. Biogeophysical studies can help guide microbial sampling thereby advancing microbial ecology studies of new microbial species associated with bioremediation.

[18] Acknowledgments. This material is partially based on work supported by Enbridge Energy (Ltd.), the Minnesota Pollution Control Agency, and the U.S.G.S. Toxic Waste Substances Program. We thank W. Herkalrath, F. Day-Lewis, J. Lane, M. Erickson, and J. Trost (U.S.G.S.), J. Heenan and C. Zhang (Rutgers-Newark) for valuable field support. B. Bekins and I. Cozzarelli (U.S.G.S) reviewed an earlier version of the manuscript. The U.S. EPA Office of Research and Development funded and collaborated in the research described here under EP-10-D-000488. It has been subjected to Agency review and approved for publication.

[19] The Editor thanks two anonymous reviewers for their assistance in evaluating this paper.

\section{References}

Amos, R. T., K. U. Mayer, B. A. Bekins, G. N. Delin, and R. L. Williams (2005), Use of dissolved and vapor-phase gases to investigate methanogenic degradation of petroleum hydrocarbon contamination in the subsurface, Water Resour. Res., 41, W02001, doi:10.1029/2004WR003433.

Baedecker, M. J., I. M. Cozzarelli, R. P. Eganhouse, D. I. Siegel, and P. C. Bennett (1993), Crude-oil in a shallow sand gravel aquifer 3. Biogeochemical reactions and mass-balance modelling in anoxic groundwater Appl. Geochem., 8(6), 569-586, doi:10.1016/0883-2927(93)90014-8.

Beal, E. J., C. H. House, and V. J. Orphan (2009), Manganese- and irondependent marine methane oxidation, Science, 325(5937), 184-187, doi:10.1126/science.1169984.

Bekins, B. A., E. M. Godsy, and E. Warren (1999), Distribution of microbial physiologic types in an aquifer contaminated by crude oil, Microb. Ecol., 37, 263-275, doi:10.1007/s002489900149.

Bekins, B. A., I. M. Cozzarelli, E. M. Godsy, E. Warren, H. I. Essaid, and M. E. Tuccillo (2001), Progression of natural attenuation processes at a crude oil spill site: II. Controls on spatial distribution of microbial populations, J. Contam. Hydrol., 53(3-4), 387-406, doi:10.1016/S0169-7722 (01)00175-9.

Bennett, P. C., D. E. Siegel, M. J. Baedecker, and M. F. Hult (1993), Crude oil in a shallow sand and gravel aquifer-I. Hydrogeology and inorganic geochemistry, Appl. Geochem., 8(6), 529-549, doi:10.1016/0883-2927 (93)90012-6.

Chaplin, B. P., G. N. Delin, R. J. Baker, and M. A. Lahvis (2002), Longterm evolution of biodegradation and volatilization rates in a crude oilcontaminated aquifer, Bioremediat. J., 6, 237-255, doi:10.1080/ 10889860290777594

Crowe, S. A., et al. (2011), The methane cycle in ferruginous Lake Matano, Geobiology, 9(1), 61-78, doi:10.1111/j.1472-4669.2010.00257.x.

Ellwood, B. B., W. L. Balsam, and H. H. Roberts (2006), Gulf of Mexico sediment sources and sediment transport trends from magnetic susceptibility measurements of surface samples, Mar. Geol., 230(3-4), 237-248, doi:10.1016/j.margeo.2006.05.008

Hanesch, M., and R. Scholger (2002), Mapping of heavy metal loadings in soils by means of magnetic susceptibility measurements, Environ. Geol., 42(8), 857-870, doi:10.1007/s00254-002-0604-1.

Hoehler, T. M., M. J. Alperin, D. B. Albert, and C. S. Martens (1994), Field and laboratory studies of methane oxidation in an anoxic marine sediment: Evidence for a methanogen-sulfate reducer consortium, Global Biogeochem. Cycles, 8(4), 451-463, doi:10.1029/94GB01800.

Kukla, G., F. Heller, L. X. Ming, X. T. Chun, L. T. Sheng, and A. Z. Sheng (1988), Pleistocene climates in China dated by magnetic susceptibility, Geology, 16(9), 811-814, doi:10.1130/0091-7613(1988)016<0811: PCICDB $>2.3$.CO;2.

Lovley, D. R., M. J. Baedecker, D. J. Lonergan, I. M. Cozzarelli, E. J. P. Phillips, and D. I. Siegel (1989), Oxidation of aromatic contaminants 
coupled to microbial iron reduction, Nature, 339(6222), 297-300, doi:10.1038/339297a0.

Molins, S., K. U. Mayer, R. T. Amos, and B. A. Bekins (2010), Vadose zone attenuation of volatile organic compounds at a crude oil spill siteInteractions between multicomponent gas transport and biogeochemical reactions, J. Contam. Hydrol., 112, 15-29, doi:10.1016/j.jconhyd. 2009.09.002.

Murphy, F., and W. N. Herkelrath (1996), A sample-freezing drive shoe for a wire line piston core sampler, Ground Water Monit. Rem., 16, 86-90, doi:10.1111/j.1745-6592.1996.tb00143.x.

Nevin, K. P., D. E. Holmes, T. L. Woodard, E. S. Hinlein, D. W. Ostendorf, and D. R. Lovley (2005), Geobacter bemidjiensis sp. nov. and Geobacter psychrophilus sp. nov., two novel Fe(III)-reducing subsurface isolates, Int. J. Syst. Evol. Microbiol., 55(4), 1667-1674, doi:10.1099/ ijs.0.63417-0.

Porsch, K., U. Dippon, M. L. Rijal, E. Appel, and A. Kappler (2010), In-situ magnetic susceptibility measurements as a tool to follow geomicrobiological transformation of Fe minerals, Environ. Sci. Technol., 44(10), 3846-3852, doi:10.1021/es903954u.

Rijal, M. L., E. Appel, E. Petrovský, and U. Blaha (2010), Change of magnetic properties due to fluctuations of hydrocarbon contaminated groundwater in unconsolidated sediments, Environ. Pollut., 158(5), 1756-1762, doi:10.1016/j.envpol.2009.11.012.
Saunders, D. F., K. R. Burson, and C. K. Thompson (1999), Model for hydrocarbon microseepage and related near-surface alterations, $A A P G$ Bull., 83(1), 170-185.

Werkema, D. D., Jr., E. A. Atekwana, A. L. Endres, W. A. Sauck, and D. P. Cassidy (2003), Investigating the geoelectrical response of hydrocarbon contamination undergoing biodegradation, Geophys. Res. Lett., 30(12), 1647, doi:10.1029/2003GL017346.

E. A. Atekwana and F. M. Mewafy, Boone Pickens School of Geology, Oklahoma State University, 105 Noble Research Ctr., Stillwater, OK 74078, USA. (estella.atekwana@okstate.edu)

G. N. Delin, U.S. Geological Survey, Denver Federal Center, MS406, Denver, CO 80225, USA.

D. Ntarlagiannis and L. D. Slater, Department of Earth and Environmental Sciences, Rutgers University, 101 Warren St., Newark, NJ 07102, USA.

A. Revil and M. Skold, Department of Geophysics, Colorado School of Mines, Golden, CO 80401, USA.

D. D. Werkema Jr., U.S. Environmental Protection Agency, Las Vegas, NV 89119, USA. 